\title{
Fast and Delayed Locomotor Response to Acute High-Dose Nicotine Administration in Adult Male Rats
}

\author{
K. JANDOVÁ ${ }^{1}$, D. MAREŠOVÁ ${ }^{1}$, J. POKORNÝ ${ }^{1}$ \\ ${ }^{1}$ Institute of Physiology, First Faculty of Medicine, Charles University in Prague, Czech Republic
}

Received March 19, 2013

Accepted July 11, 2013

\section{Summary}

The aim of the present study was to compare the immediate and delayed locomotor response to high-dose nicotine (NIC) administration in rats. The vertical and horizontal activity of behavior in adult male rats exposed to $1 \mathrm{mg} / \mathrm{kg}$ NIC or saline (SAL) were tested in a Laboras apparatus for one hour after drug application. Animals were then returned to their cages and housed for another seven days. After this period all animals were placed in Laboras again and their behavioral pattern was retested for another period of one hour (delayed response). Horizontal activity: immediately after nicotine administration animal were less mobile (first 2-minutes interval), when compared with controls. The immobilization effect of nicotine disappeared within 4 minutes and during whole first 10-minutes interval time spent by locomotion did not differ from controls. Locomotion activity of animals treated with nicotine increased robustly in following 10 minutes and remained significantly higher in 2nd, 3rd and 5th 10-minutes interval. Vertical activity: Rearing frequency was significantly lowered by NIC administration in first two minutes of the experiment and the same was found when the duration of rearing was analyzed. Lower rearing intensity of NIC treated animals disappeared in 4 minutes and was finally higher during whole test session as compared with controls. When duration of rearing was analyzed it was significantly longer in NIC treated animals. In majority of observed behavioral aspects there were no differences between NIC treated rats and controls seven days after NIC or SAL treatment. Our results reflect effect of NIC and we conclude that NIC significantly influences behavior of experimental animals.

\section{Key words}

Nicotine $\bullet$ Locomotor activity $\bullet$ Open field test $\bullet$ Adult rats

\section{Corresponding author}

Kateřina Jandová, Institute of Physiology, First Faculty of
Medicine, Charles University in Prague, Albertov 5, CZ-128 00 Prague 2, Czech Republic. E-mail: katerina.jandova@lf1.cuni.cz

\section{Introduction}

Nicotine (NIC) is everyday life drug of abuse that possesses variety of properties influencing many physiological parameters (Pelissier et al. 1998, Riljak and Langmeier 2005), interferes with learning mechanisms, memory (Ferrea and Winterer 2009, Hralová et al. 2011) and cortex excitability (Riljak et al. 2010, Riljak et al. 2012, Hralová et al. 2010) and influences results indifferent sensorimotor tests (Riljak et al. 2011b). Low doses of nicotine reduce anxiety, while higher ones cause seizures (Damaj et al. 1999, Picciotto et al. 2002). Nicotine was even repeatedly reported as drug with certain neuroprotective properties (Riljak et al. 2007, Riljak et al. 2011a). There is an evidence that the majority of above mentioned NIC properties is related to activation of nicotinic cholinergic receptors (nAChRs) and as NIC activates cholinergic receptors it influences the GABA-ergic system also, by decreasing its inhibitory input to the hippocampus, as well as the system of glutamate-related neuronal signalization (Damaj et al. 1999, Dobelis et al. 2003). Glutamate receptors mediate the excitatory neurotransmission in the hippocampus and this brain structure seems to play critical role in certain mood disorders, anxiety and depression (Joca et al. 2007). There is also an evidence that nicotine is capable to act as either depressive-like (Wallace and Potter 2011) or antidepressant agent (Tizabi et al. 2010) influencing via this mechanism the locomotor activity of NIC exposed animals.

To evaluate the behavior of experimental animals we decide to use automated observation system 
Laboras $^{\mathrm{TM}}$. Such system allows registering the duration and frequency of rearing (vertical activity) and locomotion, immobility, speed of animal reached during movement in open field and distance traveled in desired time period (horizontal activity). Since vertical activity reflects the exploratory behavior, the horizontal activity might reflect the novelty seeking behavior (Spear 2000). In the present study we have investigated if NIC administered in high dose influences the locomotor behavior of adult rats and whether this effect is long lasting. Dose of NIC chosen by us was rather high, but was chosen purposely to not trigger the seizures and tonic-clonic convulsions. To trigger the seizure pattern higher NIC doses are requested or NIC needs to be administered repeatedly (kindling protocol) (Bastlund et al. 2005). We were also interested how NIC influences the animal's habituation to novel environment. We hypothesize, that nicotine administered in high dose causes disruption in locomotor behavior (expressed as higher immobility duration) of treated rats and that this effect disappeared quickly.

\section{Methods}

\section{Animals and experiment design}

Twenty naive male Wistar albino rats were used in this experiment. The weight of animals entering the experiment was from $282 \mathrm{~g}$ to $336 \mathrm{~g}$ (test day 1). All animals were housed in standard $12 \mathrm{~h}$ light/dark cycles (with lights on at 06:00 h) in temperature-controlled environment $\left(22-23^{\circ} \mathrm{C}\right)$. All experiments took place between 08:00 and 15:00 in a room with lights on (light intensity between 150 and $200 \mathrm{~lx}$ at the level of cages). During the tests animals had not access to either food or water. Immediately after placing the animals in experimental room they were randomly assigned into two experimental groups, weighted prior each session and marked. First group was treated intraperitoneally with $1 \mathrm{mg} / \mathrm{kg}$ of (-)-nicotine (Sigma), dissolved in saline recalculated volume $1 \mathrm{mg}$ of nicotine per $1 \mathrm{ml}$ of saline. Second group was sham treated with saline (intraperitoneally) in equal volume. Animals were then placed and tested in Laboras apparatus (Metris B.V., Netherlands) to analyze their behavioral pattern for one hour (test day 1). During the measurement animals were left undisturbed. After the test session animals were returned to their home cages and housed for another seven days (food and water ad libitum). After this period all animals were placed in Laboras apparatus again and their behavioral pattern was observed for period of one hour (test day 8). All experiments were reviewed and approved by the Institutional Animal Care and Use Committee and are in agreement with the Czech Government Requirements and Requirements of European Communities Council Directive (86/609/EEC).

\section{Laboras apparatus (Metris, B.V., Netherland)}

Laboras ${ }^{\mathrm{TM}}$ is automated system for continuous behavior tracking and analysis. It consists of triangular shaped sensing platform (carbon fiber plate $700 \mathrm{~mm} \mathrm{x}$ $700 \mathrm{~mm} \times 1000 \mathrm{~mm} \times 30 \mathrm{~mm}$ ), positioned on two orthogonally placed sensor transducers and third fixed point attached to bottom plate. Makrolon cage (type III, $840 \mathrm{~cm}^{2}$ ) is placed on this platform. Mechanical vibrations generated by animal (locomotion, rearing etc.) are transformed into electrical signal. Such signals are finally processed, classified and compared by with the predetermined characteristic patterns by Laboras software. Following horizontal behavioral activities were analyzed: time of locomotion, duration of immobility, maximal speed reached within tested interval, average speed in tested interval, total distance traveled in tested interval. Vertical activities included rearing time and rearing frequency.

\section{Statistical analysis}

Data from Laboras software were in first step analyzed over ten minutes' intervals $(0-10 \mathrm{~min}, 10-$ $20 \mathrm{~min}, 20-30 \mathrm{~min}, 30-40 \mathrm{~min}, 40-50 \mathrm{~min}, 50-60 \mathrm{~min}$ ). To gain the detail information of animal's behavior the very first time interval was analyzed again over two minutes sub-interval. Each measured behavioral parameter was analyzed separately. Laboras data were subjected to non-parametric tests (because of nonGaussian data distribution). To compare the differences between particular groups within 10 minutes intervals Kruskal-Wallis test was used, same test was used to compare differences within NIC-treated group in time (test day 1 vs. test day 8 ), if $p<0.05$ results were considered as significant.

\section{Results}

All animals treated with nicotine (or saline) survived. Weight gain of animals treated with nicotine was not different $(22 \pm 2.9 \mathrm{~g})$ one week after the injection when compared with saline treated rats $(19.75 \pm 0.6 \mathrm{~g})$. 


\section{Horizontal activity}

\section{Locomotion}

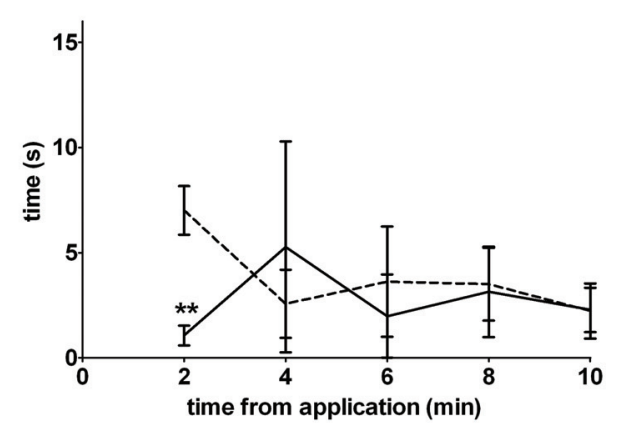

Immobility

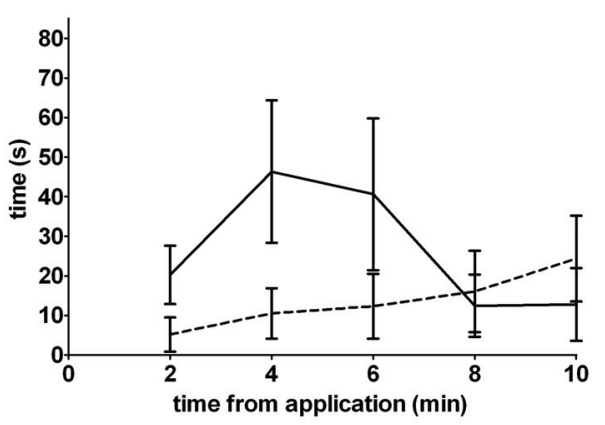

Distance

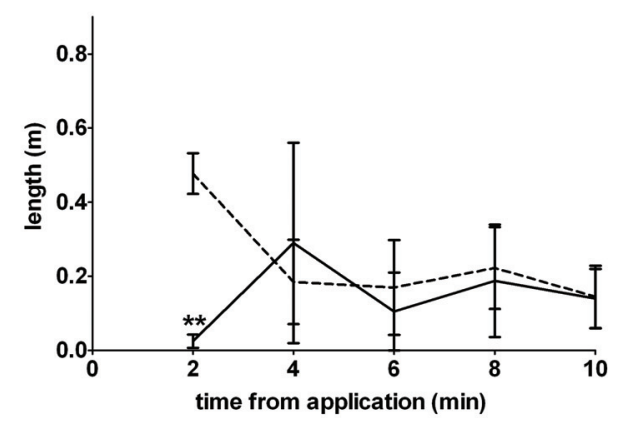

\section{Locomotion}

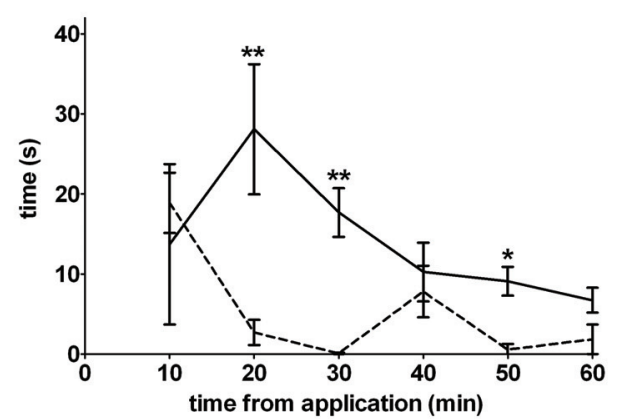

Immobility

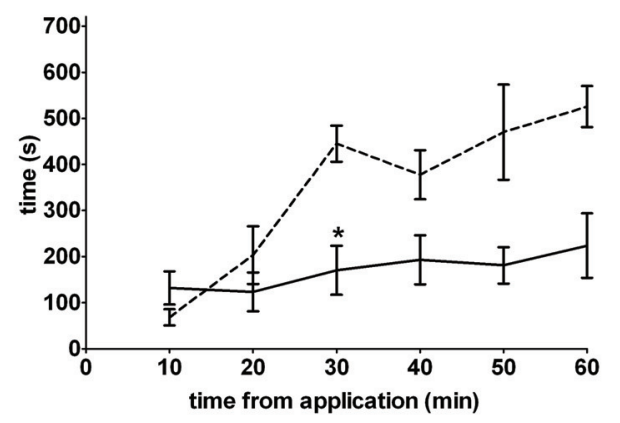

Distance

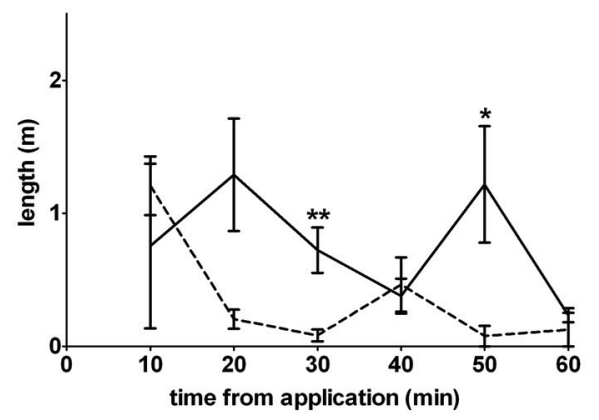

Fig. 1. Immediate NIC-induced effects on horizontal activity: locomotion (duration), immobility (duration) and distance traveled. First 10 minutes divided into five 2-minutes intervals (left part of figure), whole one hour session divided into six 10-minutes intervals (right part of figure). Solid lines represent NIC treated rats, dashed lines saline treated rats. * Results significant at $p<0.05, * *$ results significant at $\mathrm{p}<0.01, * * *$ results significant at $\mathrm{p}<0.001$. Error bars were calculated as \pm SEM.

Immediate response to nicotine administration

\section{Horizontal activity}

Immediately after nicotine administration animal were less mobile (first 2-min interval, $\mathrm{p}<0.01$ ), when compared with controls. The immobilization effect of nicotine disappeared within 4 minutes and during whole first 10-min interval time spent by locomotion did not differ from controls. Locomotion activity of animals treated with nicotine increased robustly in following 10 minutes and remained significantly higher in $2^{\text {nd }}, 3^{\text {rd }}$ $(\mathrm{p}<0.01)$ and $5^{\text {th }}(\mathrm{p}<0.05) 10$-minutes interval. In last part of the test session ( $6^{\text {th }}$ interval) NIC animals did not differ from controls. Increased duration of locomotion was partially followed by shorter time, that NIC treated animals spent as immobile ( $3^{\text {rd }}$ interval, $\left.p<0.05\right)$ (Fig. 1).

Lower horizontal activity immediately after NIC treatment was reflected by shorter distance traveled in first two minutes $(\mathrm{p}<0.01)$, but increased within the test session and was significantly longer in $3^{\text {rd }}(\mathrm{p}<0.01)$ and $5^{\text {th }} 10$-min time interval $(\mathrm{p}<0.05)$ (Fig. 1).

Control animals reached significantly higher 


\section{Horizontal activity}

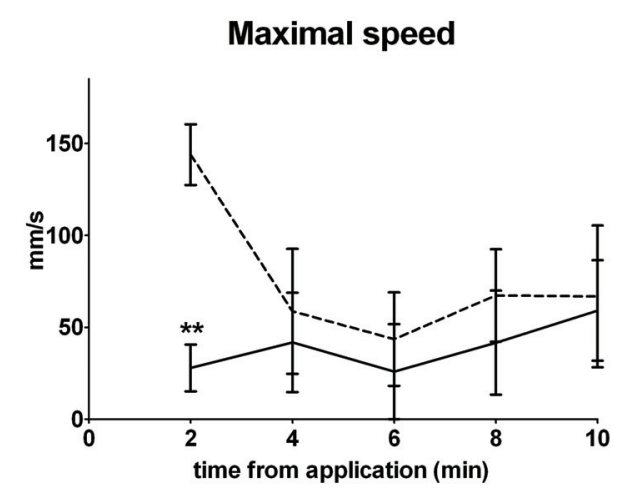

Average speed

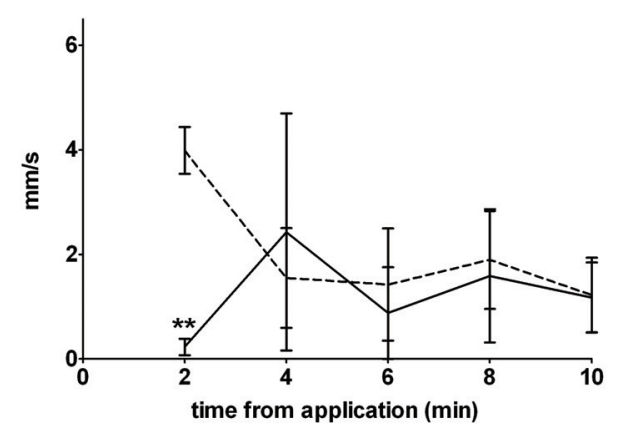

Maximal speed

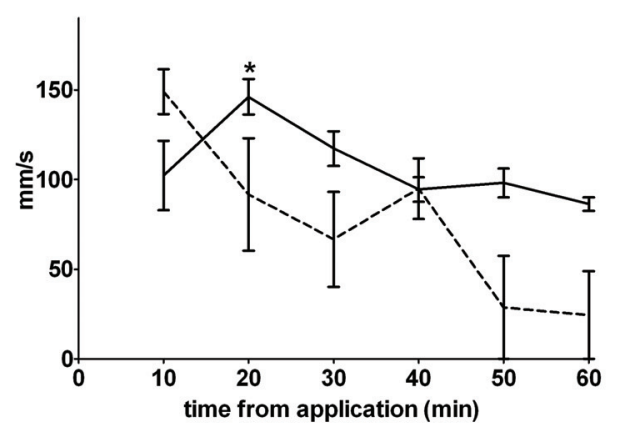

Average speed

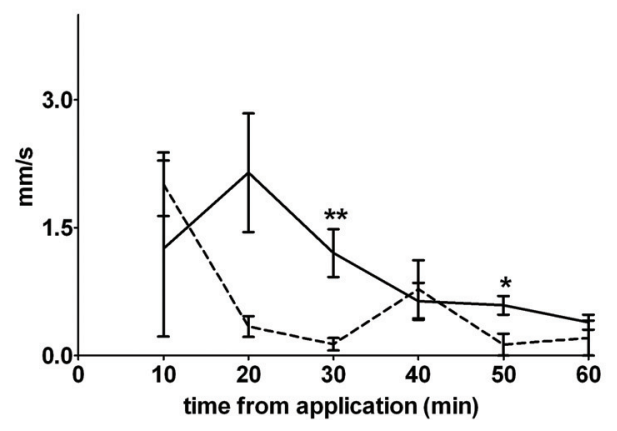

Fig. 2. Immediate NIC-induced effects on horizontal activity: maximal and average speed. First 10 minutes divided into five 2-minutes intervals (left part of figure), whole one hour session divided into six 10-minutes intervals (right part of figure). Solid lines represent NIC treated rats, dashed lines saline treated rats. $*$ Results significant at $\mathrm{p}<0.05, * *$ results significant at $\mathrm{p}<0.01, * * *$ results significant at $\mathrm{p}<0.001$. Error bars were calculated as $\pm \mathrm{SEM}$.

maximal $(\mathrm{p}<0.01)$ and average $(\mathrm{p}<0.01)$ speed in first 2 minutes of the test session, but this effect disappeared in 4 minutes and NIC treated reached finally higher values of maximal speed $\left(2^{\text {nd }}\right.$ interval, $\left.p<0.05\right)$ and average speed $\left(3^{\text {rd }}\right.$ interval, $\mathrm{p}<0.01$ and $5^{\text {th }}$ interval, $\mathrm{p}<0.05$ ) (Fig. 2).

\section{Vertical activity}

Time spent rearing was significantly lowered by NIC administration in first 2 minutes of the experiment $(\mathrm{p}<0.01)$ and the same was found, when rearing frequency was analyzed $(p<0.01)$. Lower rearing intensity of NIC treated animals disappeared in 4 minutes and was finally higher during whole test session (except the interval $5^{\text {th }}$ ) as compared with controls. When duration of rearing was analyzed it was significantly longer in NIC treated animals $\left(5^{\text {th }}\right.$ interval $\mathrm{p}<0.01,6^{\text {th }}$ interval, $\left.\mathrm{p}<0.05\right)$ (Fig. 3).

\section{Delayed response to nicotine administration}

In majority of observed behavioral aspects there were no differences between NIC treated rats and controls. Week after NIC administration animals embodied only few significantly different values. Duration of immobility was lower in NIC group between 10-20 minutes of data collection $(\mathrm{p}<0.01)$ and rearing frequency was higher in NIC treated animals between 1020 minutes of experiment $(\mathrm{p}<0.05)$ (Fig. 4).

\section{Discussion}

In the present study we evaluated behavioral response to nicotine administration to adult male rats. For this purpose we used the automated behavioral observation system Laboras ${ }^{\mathrm{TM}}$. Locomotor activity is widely used to study different behavioral actions, mainly psychomotor stimulant ones in rats (Collins et al. 1988, Paulus and Gayer 1991, Slamberová et al. 2011, 2012).

Locomotion, especially horizontal activity, has been used to quantify genetically sex, age and event strain based differences in nicotine treated animals. In addition, different aspects of locomotion - horizontal and vertical activity - have been interpreted to reflect different behavioral processes. Horizontal activity has 


\section{Vertical activity}

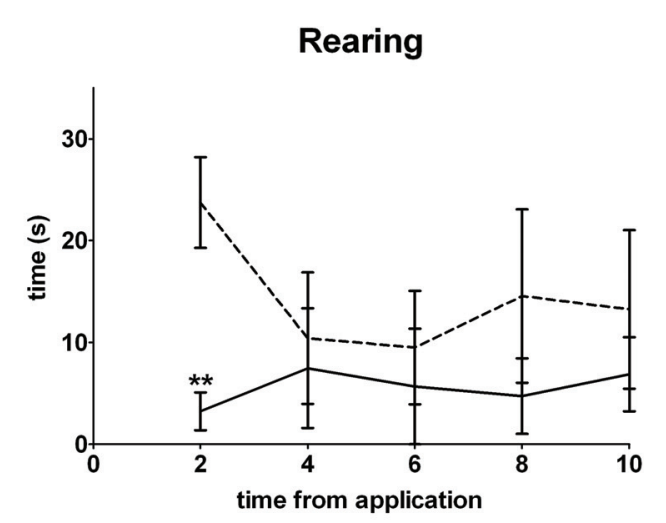

Rearing frequency

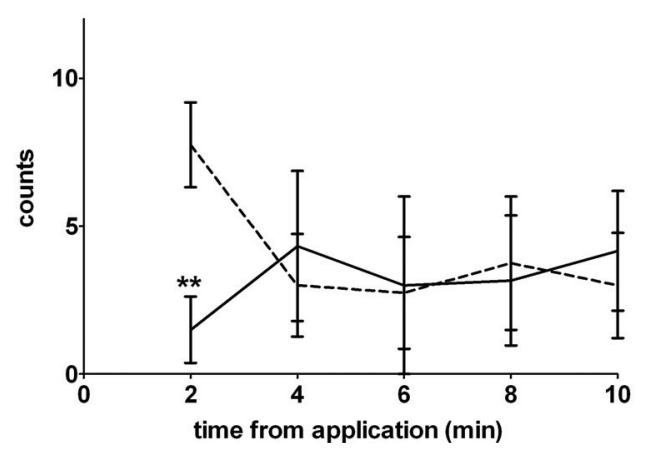

Rearing

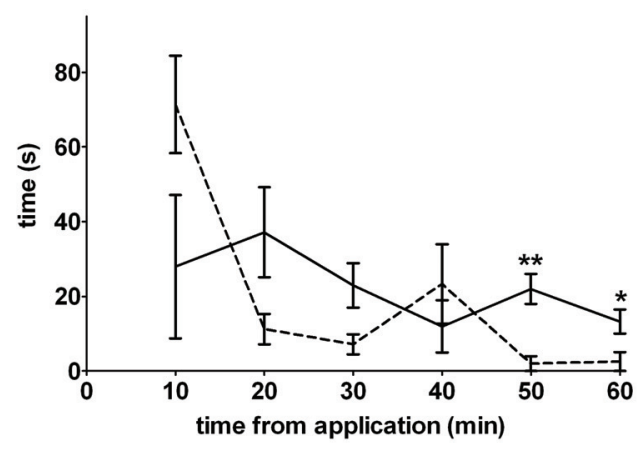

Rearing frequency

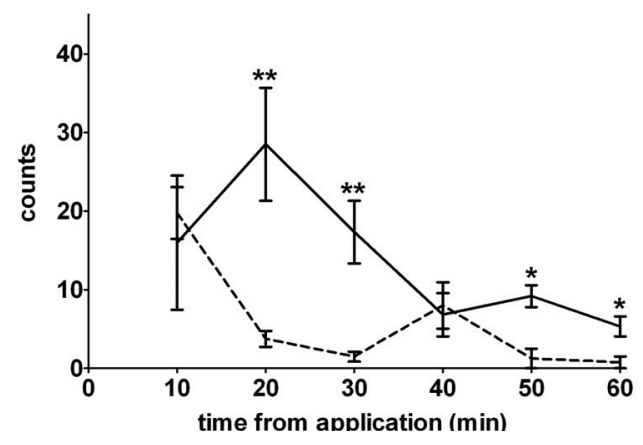

Fig. 3. Immediate NIC-induced effects on vertical activity: rearing and rearing frequency. First 10 minutes divided into five 2-minutes intervals (left part of figure), whole one hour session divided into six 10-minutes intervals (right part of figure). Solid lines represent NIC treated rats, dashed lines saline treated rats. * Results significant at $\mathrm{p}<0.05, * *$ results significant at $\mathrm{p}<0.01, * * *$ results significant at $\mathrm{p}<0.001$. Error bars were calculated as \pm SEM.

been interpreted to reflect general arousal; vertical activity is thought to indicate exploration (Ader and Conklin 1963, Walsh and Cummins 1975, Crawley et al. 1997).

Nicotine has significant and complex effects on the locomotor activity of rats depending on dose sex and age (Ksir 1994, Faraday et al. 2003). When our data from Laboras were analyzed over two minute intervals we found that immediately after nicotine administration the animals exhibited longer time spent by locomotion, and this effect could be only hardly attribute to injection procedure, because control animals were treated with saline same way. Control animals that have not been habituated to the testing apparatus, demonstrated high initial levels signs of horizontal activity and exploratory behavior (rearing). The decreased horizontal locomotor activity of NIC treated rats could very probably attribute to its action at peripheral nAChRs such as an overload neuromuscular junction (Leonard and Bertrand 2001, MacDermott et al. 1999). Nicotine then immediately induced a suppression of locomotor activity as measured horizontal activity and rearing in an open field. This similar effect of NIC was described by us previously in immature rats (Riljak et al. 2011b). In this experiment $1 \mathrm{mg}$ of NIC was capable to prolong the latency to the surface righting response and prolongs the times in simple negative geotaxis test.

Increased behavioral activity in NIC group rats was appeared in subsequent time intervals. We can speculate this rapidly depressant effect of NIC is replaced by influence of some nicotine-stimulated neurotransmitter systems such as dopamine that is influencing the locomotor activity significantly. Such hypothesis supported by other authors as well, e.g. acute NIC injections have been shown to increase level of plasma adrenocorticotropic hormone (ACTH) (Matta et al. 1987), 


\section{Horizontal activity}

\section{Locomotion}

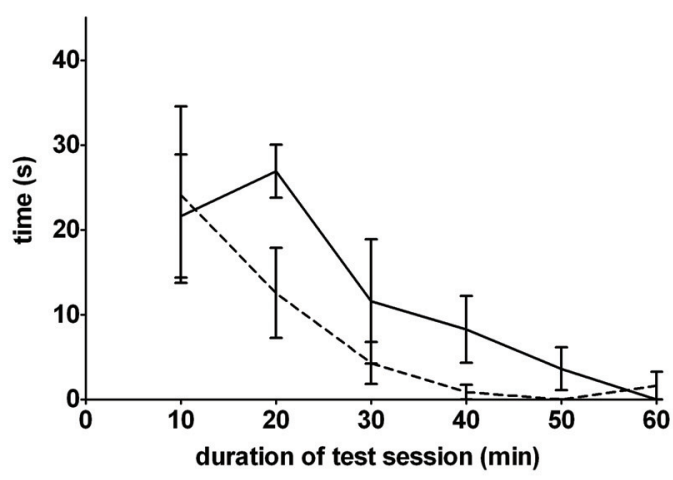

Maximal speed

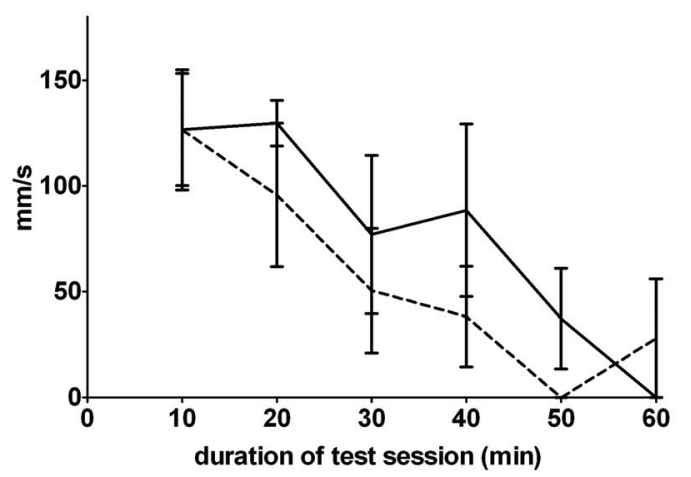

Immobility

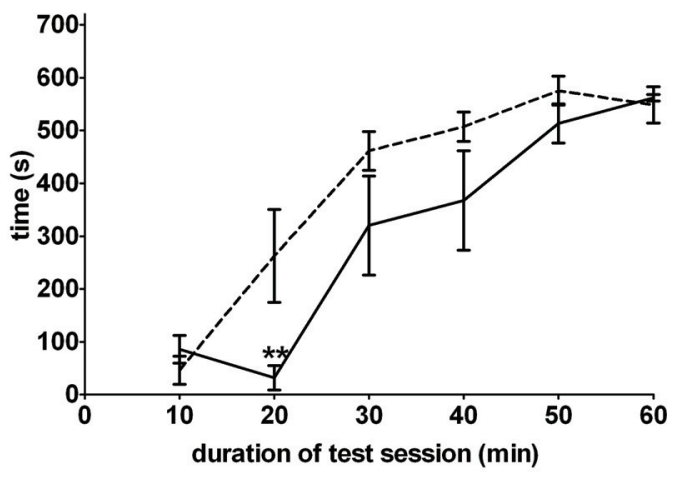

Distance

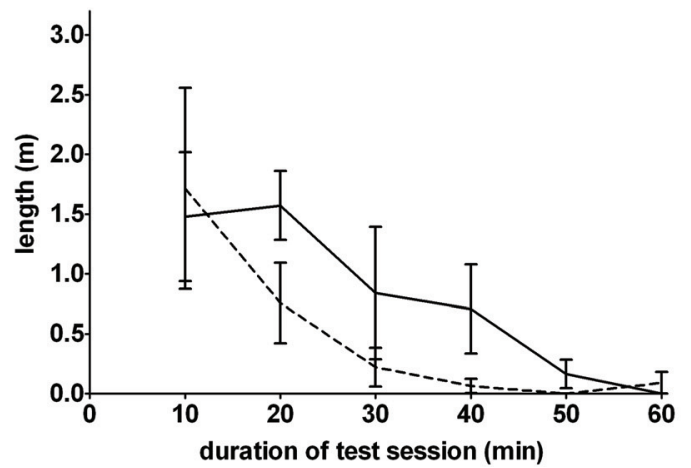

\section{Vertical activity}

Rearing

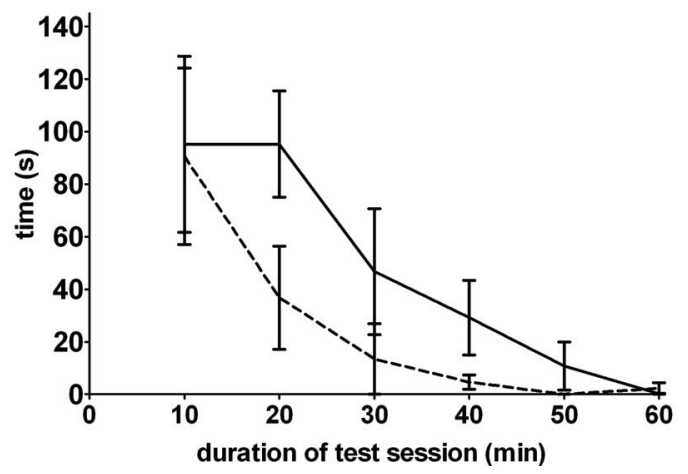

Rearing frequency

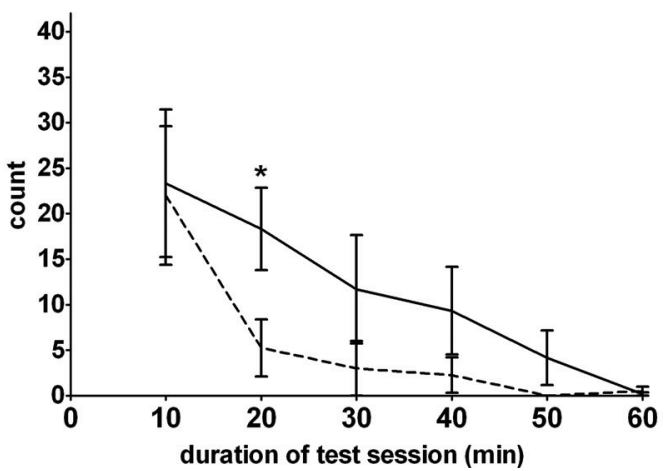

Fig. 4. Delayed NIC-induced effects on vertical and horizontal activity. Whole one hour session divided into six 10-minutes intervals. Solid lines represent NIC treated rats, dashed lines saline treated rats. * Results significant at $p<0.05, * *$ results significant at $p<0.01$. Error bars were calculated as \pm SEM. 
follow by increased plasma corticosterone levels (Cagguila et al. 1991). Latter hormone can finally enhance the release of dopamine in nucleus accumbens via e.g. NIC (Rouge-Pont et al. 1998). It seems to very probably, that the mentioned steroid hormones play important role in nicotine-mediated changes of rats' locomotor activity, because repeated nicotine injection reduces ACTH levels (Benwell and Balfour 1979). So even, experimental design (single vs. repeated nicotine injection) plays crucial role in final locomotion pattern of tested animals. Another important mechanism influencing the outcomes of open field test is the anxiogenic/anxiolytic-like effect of NIC administration. In general it is believed that low doses of NIC $(0.1 \mathrm{mg} / \mathrm{kg}$ app.) have an anxiolytic effect, while the higher ones have anxiogenic impact (1 mg/kg app.) (File et al. 1998). That mechanism should be taken in account when interpreting locomotion-related data.

As can be seen sign of exploratory behavior rearing activity - was increased by nicotine nearly during the test session, so animals did not demonstrate the process of habituation (as observed in controls).

In conclusion, majority of described effect disappeared completely in one week that leads us conclusion that nicotine affects behavior of animals (in our experimental paradigm) momentarily and transiently.

\section{Conflict of Interest}

There is no conflict of interest.

\section{Acknowledgements}

This study was supported by grant by PRVOUKP34/LF1/7.

\section{References}

ADER R, CONKLIN PM: Handling of pregnant rats: effects on emotionality of their offspring. Science 142: 411-412, 1963.

BASTLUND JF, BERRY D, WATSON WP: Pharmacological and histological characterisation of nicotine-kindled seizures in mice. Neuropharmacology 48: 975-983, 2005.

BENWELL MEM, BALFOUR DJK: Effects of nicotine administration and its withdrawal on plasma corticosterone and brain 5-hydroxyindoles. Psychopharmacology 63: 7-11, 1979.

CAGGIULA AR, EPSTEIN LH, ANTELMAN SM, SAYLOR SS, PERKINS KA, KNOPF S, STILLER R: Conditioned tolerance to the anorectic and corticosterone-elevating effects of nicotine. Pharmacol Biochem Behav 40: 53-59, 1991.

COLLINS AC, MINER LL, MARKS MJ: Genetic influences on acute responses to nicotine and nicotine tolerance in the mouse. Pharmacol Biochem Behav 30: 269-278, 1988.

CRAWLEY JN, BELKNAP JK, COLLINS A, CRABBE JC, FRANKEL W, HENDERSON N, HITZEMANN RJ, MAXSON SC, MINER LL, SILVA AJ, WEHNER JM, WYNSHAW-BORIS A, PAYLOR R: Behavioral phenotypes of inbred mouse strains: implications and recommendations for molecular studies. Psychopharmacology 132: 107-124, 1997.

DAMAJ MI, GLASSCO W, DUKAT M, MARTIN BR: Pharmacological characterization of nicotine-induced seizures in mice. J Pharmacol Exp Ther 291: 1284-1291, 1999.

DOBELIS P, HUTTON S, LU Y, COLLINS AC: GABAergic systems modulate nicotinic receptor-mediated seizures in mice. J Pharmacol Exp Ther 306: 1159-1166, 2003.

FARADAY MM, O'DONOGHUE VA, GRUNBERG NE: Effects of nicotine and stress on locomotion in SpragueDawley and Long-Evans male and female rats. Pharmacol Biochem Behav 74: 325-333, 2003.

FERREA S, WINTERER G: Neuroprotective and neurotoxic effects of nicotine. Pharmacopsychiatry 42: 255-265, 2009.

FILE SE, KENNY PJ, OUAGAZZAL A-M: Bimodal modulation by nicotine of anxiety in the social interaction test: role of dorsal hippocampus. Behav Neurosci 112: 1423-1429, 1998.

HRALOVÁ M, MAREŠOVÁ D, RILJAK V: Effect of the single-dose of nicotine-administration on the brain bioelectrical activity and on behaviour in immature 12-day-old rats. Prague Med Rep 111: 182-190, 2010.

HRALOVÁ M, MAREŠOVÁ D, RILJAK V: Is learning ability and spatial memory in rats influenced by single dose of nicotine? Prague Med Rep 112: 193-204, 2011. 
JOCA SR, FERREIRA FR, GUIMARÃES FS: Modulation of stress consequences by hippocampal monoaminergic, glutamatergic and nitrergic neurotransmitter systems. Stress 10: 227-249, 2007.

KSIR C: Acute and chronic nicotine effects on measures of activity in rats: a multivariate analysis. Psychopharmacology 115: 105-109, 1994.

LEONARD S, BERTRAND D: Neuronal nicotinic receptors: from structure to function. Nicotine Tob Res 3: 203-223, 2001.

MACDERMOTT AB, ROLE LW, SIEGELBAUM SA: Presynaptic ionotropic receptors and the control of transmitter release. Annu Rev Neurosci 22: 443-485, 1999.

MATTA SG, BEYER HS, MCALLEN KM, SHARP BM: Nicotine elevates rat plasma ACTH by a central mechanism. J Pharmacol Exp Ther 243: 217-226, 1987.

PAULUS MP, GEYER MA: A temporal and spatial scaling hypothesis for the behavioral effects of psychostimulants. Psychopharmacology 104: 6-16, 1991.

PELISSIER AL, GANTENBEIN M, BRUGUEROLLE B: Nicotine-induced perturbations on heart rate, body temperature and locomotor activity daily rhythms in rats. J Pharm Pharmacol 50: 929-934, 1998.

PICCIOTTO MR, BRUNZELL DH, CALDARONE BJ: Effect of nicotine and nicotinic receptors on anxiety and depression. Neuroreport 13: 1097-1110, 2002.

RILJAK V, LANGMEIER M: Nicotine an efficient tool of the neurobiological research today, the tool of treatment tomorrow? Prague Med Rep 106: 329-348, 2005.

RILJAK V, MILOTOVÁ M, JANDOVÁ K, POKORNÝ J, LANGMEIER M: Morphological changes in the hippocampus following nicotine and kainic acid administration. Physiol Res 56: 641-649, 2007.

RILJAK V, MARESOVA D, POKORNY J: Nicotine effects on rat seizures susceptibility and hippocampal neuronal degeneration. Neuro Endocrinol Lett 31: 792-795, 2010.

RILJAK V, BENES J, POKORNÝ J, MYSLIVECEK J: Neuroprotective effect of nicotine against kainic acid excitotoxicity is associated with alpha-bungarotoxin insensitive receptors subtype of nAChRs. Neuro Endocrinol Lett 32: 816-820, 2011a.

RILJAK V, MAREŠOVÁ D, DOHNALOVÁ A, POKORNÝ J: Nicotine influences the motor performance of immature rats in two different sensorimotor tasks. Prague Med Rep 112: 177-183, $2011 \mathrm{~b}$.

RILJAK V, MAREŠOVÁ D, JANDOVÁ K, POKORNÝ J: Nicotine and kainic acid effects on cortical epileptic afterdischarges in immature rats. Physiol Res 61: 537-542, 2012.

ROUGE-PONT F, DEROCHE V, LE MOAL M, PIAZZA PV: Individual differences in stress-induced dopamine release in the nucleus accumbens are influenced by corticosterone. Eur J Neurosci 10: 3903-3907, 1998.

SLAMBEROVÁ R, SCHUTOVÁ B, HRUBÁ L, POMETLOVÁ M: Does prenatal methamphetamine exposure affect the drug-seeking behavior of adult male rats? Behav Brain Res 224: 80-86, 2011.

SLAMBEROVÁ R, YAMAMOTOVÁ A, POMETLOVÁ M, SCHUTOVÁ B, HRUBÁ L, NOHEJLOVÁ-DEYKUN K, NOVÁ E, MACÚCHOVÁ E: Does prenatal methamphetamine exposure induce cross-sensitization to cocaine and morphine in adult male rats? Prague Med Rep 113: 189-205, 2012.

SPEAR LP: The adolescent brain and age-related behavioral manifestations. Neurosci Biobehav Rev 24: 417-463, 2000.

TIZABI Y, HAUSER SR, TYLER KY, GETACHEW B, MADANI R, SHARMA Y, MANAYE KF: Effects of nicotine on depressive-like behavior and hippocampal volume of female WKY rats. Prog Neuropsychopharmacol Biol Psychiatry 34: 62-69, 2010.

WALLACE TL, PORTER RH: Targeting the nicotinic alpha7 acetylcholine receptor to enhance cognition in disease. Biochem Pharmacol 82: 891-903, 2011.

WALSH RN, CUMMINS RA: Mechanisms mediating the production of environmentally induced brain changes. Psychol Bull 82: 986-1000, 1975. 